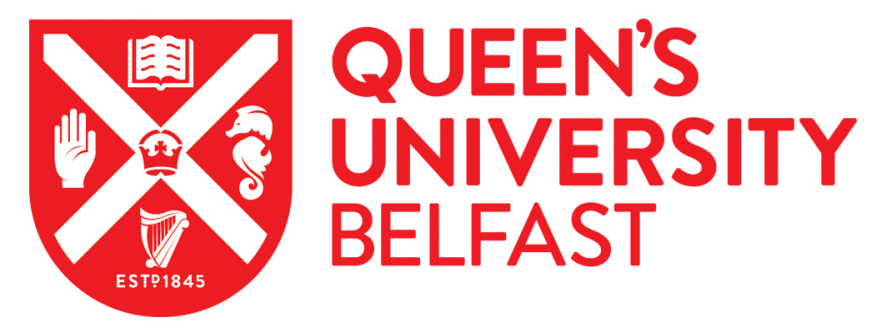

\title{
A comprehensive review of food fraud terminologies and food fraud mitigation guides
}

Robson, K., Dean, M., Haughey, S., \& Elliott, C. (2020). A comprehensive review of food fraud terminologies and food fraud mitigation guides. Food Control, [107516]. https://doi.org/10.1016/j.foodcont.2020.107516

\author{
Published in: \\ Food Control
}

Document Version:

Peer reviewed version

Queen's University Belfast - Research Portal:

Link to publication record in Queen's University Belfast Research Portal

Publisher rights

(c) 2020 Elsevier Ltd. All rights reserved.

This manuscript is distributed under a Creative Commons Attribution-NonCommercial-NoDerivs License

(https://creativecommons.org/licenses/by-nc-nd/4.0/), which permits distribution and reproduction for non-commercial purposes, provided the author and source are cited.

\section{General rights}

Copyright for the publications made accessible via the Queen's University Belfast Research Portal is retained by the author(s) and / or other copyright owners and it is a condition of accessing these publications that users recognise and abide by the legal requirements associated with these rights.

Take down policy

The Research Portal is Queen's institutional repository that provides access to Queen's research output. Every effort has been made to ensure that content in the Research Portal does not infringe any person's rights, or applicable UK laws. If you discover content in the Research Portal that you believe breaches copyright or violates any law, please contact openaccess@qub.ac.uk. 

guides

\section{Authors names and affiliations:}

1. Miss Kelsey Robson ${ }^{1,2}$

Krobson02@qub.ac.uk

2. Professor Moira Dean ${ }^{1}$

Moira.dean@qub.ac.uk

3. Dr. Simon Haughey ${ }^{1}$

s.a.haughey@qub.ac.uk

4. Professor Christopher Elliott ${ }^{1}$

Chris.elliott@qub.ac.uk

${ }^{1}$ Queens University Belfast, Institute for Global Food Security, Biological Sciences Building, 19 Chlorine Gardens, Belfast BT9 5DL, United Kingdom

${ }^{2}$ ABP Food Group, John St, Mulladrillen, Ardee, Co. Louth, A92 C92H, Ireland

\section{Corresponding Author:}

Christopher Elliott

Chris.elliott@qub.ac.uk

\section{Highlights:}

- Food fraud definitions share common themes of intentional acts and economic motivation.

- Lack of consistent 'types' of food fraud creates confusion over how fraud is described.

- Of the twelve food fraud mitigation documents found none focused on the beef supply chain.

\section{Abstract:}

Due to constant integrity challenges, ambiguous definitions, and lack of specific guidance, the food industry has been left vulnerable to food fraud. Food fraud is undefined by the EU, resulting in the creation of varying definitions from researchers and regulatory bodies. Not having a definition of food fraud and related terms makes it challenging to comprehend, communicate and ideate on how to prevent it. Furthermore, the food industry is lacking clear guidance on the prevention and mitigation of food fraud. Several documents are available to help guide the food industry; however, they are nonspecific to supply chains, which has left a substantial gap in knowledge that is necessary 
to protect the food supply. This review analyzed definitions for food fraud and related terms, as well as current guidance on food fraud prevention and mitigation, which can be utilized by the food industry to find commonality and assess where more information is needed. An abundance of literature describing food fraud was found, and although definitions varied, the common themes of intentional acts and economic motivation were widespread. Additionally, general guidance documents for food fraud mitigation and prevention shared general ideas of supply chain transparency, supplier audits, horizon scanning, and vulnerability assessment, which could be utilized throughout the food industry.

\section{Keywords}

Food fraud, Prevention, Mitigation

\section{Funding}

This review was funded by the European Institute of Innovation and Technology (EIT) (Food Fortress/ R6603GFS) and ABP Food Group.

Food fraud dates back to ancient Rome and Athens where there were laws regarding the adulteration of wines with flavours and colours (Sumar \& Ismail, 1995). Even though food fraud is an old problem it is still occurring. Although the true extent cannot be known food fraud is undoubtedly cheating hundreds of millions of pounds form the food industry as well as from the consumers each year in the UK alone (Shears, 2010). Food fraud is an issue affecting all food supply chains and therefore the entire food industry, customers and consumers. Food supply chains are increasing vulnerable due to globalisation and lengthening of supply chains (Lotta \& Bogue, 2015; Trivedi et al., 
2016). Therefore, the need for sophisticated food fraud prevention and mitigation is greater than ever. However, the fight against food fraud is hindered by ambiguity concerning the term (Wisniewski \& Buschulte, 2019). The European Union (EU) has not set a legal definition for what food fraud is and this has led to inconsistencies among researchers and regulatory bodies, confusing the understanding of food fraud and related terms (Wisniewski \& Buschulte, 2019; Lotta \& Bogue, 2015; Spink et al., 2015). The food industry is in the unique position of being a victim of food fraud and also largely liable for food fraud incidents (Wisniewski \& Buschulte, 2019). Therefore, the food industry is in need of a clear understanding of food fraud, as well as guidance on food fraud prevention and mitigation. A range of academic literature, government publications, stakeholders have defined food fraud and offered guidance on and mitigation strategies. However, within these documents definitions of food fraud often differ, as well as on the types of food fraud that can occur. Therefore, prevention and mitigations strategies are generalized and not specific to a particular supply chain which adds to the ambiguity.

This literature review deconstructed the definitions of food fraud and related terminology, and examined current guidance for food fraud prevention and mitigation. By determining the current state of available guidance and understanding surrounding food fraud, this review aimed to point out gaps that need to be filled. This will identify future works needed to protect food products from fraud. 
In this literature review searches were carried out to define food fraud and related terms.

Databases (Science Direct, Scopus, Web of Science) were searched for definitions of food fraud, economically motivated adulteration (EMA), food integrity, food crime and food authenticity. The searches found 231 articles, of which 107 duplicates were removed and abstracts read to determine relevance. A total of 35 articles of interest where taken forward.

The searches revealed twelve definitions for food fraud in peer-reviewed literature. These definitions are shown in Table 1. A majority of definitions agree that food fraud is an intentional deception for economic gain using food. Within the definitions for food fraud, the motivation or driving factor for economic gain is generally agreed. This is seen in all definitions except for Manning (2016) which instead stated the motivation as "encourage[ing] another individual erroneously to part with something of intrinsic value". Although gain due to fraudulent behaviour is not explicitly mentioned in Manning (2016) the objective to exploit an unsuspecting party is still indicated. Cruse (2019) states that economic benefit is one motivation for food fraud, however, one can also be motivated by an intent to cause harm. This point of view is not supported by other definitions, although malicious contamination is considered a type of fraud, which will be discussed in section 9 . Many articles state that food fraud may cause unintentional harm, however this is generally a ramification of product substitution or cheap, unhygienic processing, leading to food safety issues (Manning \& Soon, 2016; Spink, Moyer \& Speirer- Pero, 2016; Zhang \& Xue, 2016). All of the definitions described in Table 1 state that food fraud is intentional or deliberate and if contamination occurs unintentionally this is not an act of fraud but a food safety incident.

\section{Table 1. Food fraud definitions form academic literature}


Food fraud is a collective term used to encompasses the deliberate and intentional substitution, addition, tampering or misrepresentation of food, food ingredients or food packaging: of false or misleading statements made about a product, for economic gain.

\section{Everstine, Spink \& \\ Kennedy, 2013}

Ellis Muhamadali,
Haughey, Elliott, \&
Goodacre, 2015

The intentional adulteration of food for financial advantage.

Committed when food is deliberately placed on the market for financial gain, with the intent of deception of consumers. Referred to in the USA and occasionally elsewhere as economically motivated adulteration (EMA). Two of the main types include: trading of food which is unfit for consumption or harmful, or deliberately misdescribing or mislabelling food. The latter can include false statements regarding geographical origin, ingredients, or substitution with lower value (i.e. myrtle instead of oregano), or sometimes even dangerous contents not intended for human consumption (i.e. industrial dyes). The terms food fraud and food adulteration can be used to mean the same thing, when adulteration is intentional.

\begin{tabular}{l}
\hline Spink et al., 2015 \\
\hline Charlebois, Schwab, \\
Henn, \& Huck, 2016 \\
\hline Manning, 2016 \\
\hline $\begin{array}{l}\text { Moyer, DeVries \& Spink, } \\
2017\end{array}$
\end{tabular}
An international act with motivation for economic gain.

The deliberate intent to deceive, motivated by the prospect of financial gain. The intentional misrepresentation of fact by one person solely, or acting on behalf of an organization, in order to encourage another individual erroneously to part with something of intrinsic value.

Food fraud (including the subcategory the US Food and Drug Administration (FDA) defined as Economically Motivated Adulteration (EMA)) is illegal deception for economic gain using food.

Spink et al., 2017 Illegal intentional deception for economic gain using food-can occur in all stages of the supply chain and often cross international borders.

Food fraud covers cases where there is a violation of EU food law, which is committed intentionally to pursue an economic or financial gain through consumer deception. Food fraud in the food supply chain can arise as a result of misrepresentation

Bouzembrak, Steen, Neslo, Linge, Mojtahed, \& Marvin., 2018 associated with: product integrity (e.g. counterfeit product, expiration date), process integrity (e.g. diversion of products outside of intended markets), people integrity (e.g. characterizations such as the cyber criminals and hacktivist) and data integrity (e.g. improper, expired, fraudulent or missing common entry documents or health certificates) of information accompanying the food item throughout the supply chain.

Cruse, 2019 An intentional change in a food product that a consumer is unaware of with their purpose to deceive consumers- whether to cause harm or to economically benefit. Intentional modification of food products and/or associated documentation for Manning and Soon, 2019 economic gain and may lead to issues of food safety, legality and/or quality depending on the activities undertaken or the agent(s) used. Long Definition: Illegal deception for economic gain using food encompasses deliberate and intentional substitution, addition, tampering, or misrepresentation of

Spink et al., 2019a food, food ingredients, or food packaging; or false or misleading statements made about a product for economic gain. The types of fraud include adulteration, tampering, product overrun, theft, diversion, simulation, and counterfeiting.

Spink, 2019; Spink et al., 2019a; Spink, Chen, Zhang, \& Speier-Pero, 2019b
Short Definition: Illegal deception for economic gain using food 
110 Further definitions of food fraud exist in the grey literature which includes publications from government bodies, regulatory standards, and stakeholders (Table 2). Similar to the definitions found in the academic literature, definitions of food fraud in the grey literature largely include intentional deception for economic gain. The motivation of economic or financial gain is seen in ten of the thirteen definitions as shown in Table 2. PAS 96: 2017 does not directly state financial gain as a motive, but instead states that personal gain is one motive for food fraud, which may include financial gain. PAS 96: 2017 also states that another motivation for food fraud may be to cause another party financial loss. The Food Fraud Mitigation Guidance from USP (2016) does not give motivation in its definition of food fraud but does say that one type of food fraud-EMA is intentional and motivated by financial gain. Additionally, the Counter fraud good practice for food and drink businesses (2016) does not state motivation. That maybe because Counter fraud good practice for food and drink businesses applies the definition of fraud, as seen in the Fraud Act 2006 to food fraud, instead of creating a specific definition for food fraud. CWA 17369 (2019) does not limit the motivation of food fraud to economic gain only. Therefore, motivations could include intent to harm, the ethical reason of a business, or individual or market pressure (van Ruth, Huisman \& Luning, 2017). However, CWA 17369 (2019) does note that "financial gain is the most common motivation for food fraud", and argues that intention can be hard to prove. Therefore, the inclusion of motivation in a definition of food fraud may be problematic, as it will be difficult to establish. However, most definitions found in Tables $\mathbf{1}$ and $\mathbf{2}$ agree that food fraud is an intentional and deceptive act for economic gain in food.

Table 2. Food fraud definitions in standards and publications from government bodies and stakeholders

\begin{tabular}{ll}
\hline Source & Definition \\
\hline $\begin{array}{l}\text { Elliott review into the } \\
\text { integrity and }\end{array}$ & $\begin{array}{l}\text { Deliberately placing food on the market, for financial gain, with the intention of deceiving } \\
\text { the consumer. Although there are many kinds of food fraud, the two main types are: }\end{array}$ \\
assurance of food & $\begin{array}{l}\text { Sale of food which is unfit and potentially harmful, such as: -recycling of animal by- } \\
\text { products back into the food chain -packing and selling of beef and poultry with an }\end{array}$ \\
\hline
\end{tabular}


supply networks

(DEFRA, 2014) unknown origin -knowingly selling goods which are past their 'use by' date. • Deliberate misdescription of food such as: -products substituted with a cheaper alternative, for example farmed salmon sold as wild, and Basmati rice adulterated with cheaper varieties. -making false statements about the source of ingredients, i.e. their geographic, plant or animal origin. Food fraud may also involve the sale of meat from animals that have been stolen and/or illegally slaughtered, as well as wild game animals like deer that may have been poached.

Food fraud is committed when food is deliberately placed on the market for financial gain, with the intention of deceiving consumers or customers. steps to help protect your business (FDF, 2014)

\begin{tabular}{|c|c|}
\hline $\begin{array}{l}\text { Food fraud and } \\
\text { "Economically } \\
\text { Motivated } \\
\text { Adulteration" of food } \\
\text { and food ingredient } \\
\text { (CRS, 2014) }\end{array}$ & The act of defrauding buyers of food and food ingredients for economic gain. \\
\hline $\begin{array}{l}\text { GFSI Position on } \\
\text { mitigating the } \\
\text { public health risk of } \\
\text { food fraud (GFSI, 2014) }\end{array}$ & $\begin{array}{l}\text { Food fraud, including the subcategory of economically motivated adulteration, is of } \\
\text { growing concern. It is deception of consumers using food products, ingredients and } \\
\text { packaging for economic gain and includes substitution, unapproved enhancements, } \\
\text { misbranding, counterfeiting, stolen goods or other. }\end{array}$ \\
\hline $\begin{array}{l}\text { Counter fraud good } \\
\text { practice for food and } \\
\text { drink businesses } \\
(\mathrm{CIEH}, 2016)\end{array}$ & $\begin{array}{l}\text { The criminal law in England \& Wales concerning fraud is primarily derived from the Fraud } \\
\text { Act } 20064 \text {. There are three ways to commit fraud under the Fraud Act 2006: } \\
\text { - By false representation. } \\
\text { - By failing to disclose information. } \\
\text { - By abusing a position of trust. }\end{array}$ \\
\hline $\begin{array}{l}\text { Food fraud Mitigation } \\
\text { Guidance (USP, 2016) }\end{array}$ & Food fraud encompasses a wide range of deliberate fraudulent acts to food. \\
\hline $\begin{array}{l}\text { Food fraud } \\
\text { vulnerability } \\
\text { assessment and } \\
\text { mitigation (PwC, 2016) }\end{array}$ & Food fraud is simply defined as intentional deception using food for economic gain. \\
\hline $\begin{array}{l}\text { PAS } 96: 2017 \text { - Guide to } \\
\text { protecting and } \\
\text { defending food and } \\
\text { drink from deliberate } \\
\text { attack (BSI, 2017) }\end{array}$ & $\begin{array}{l}\text { Dishonest act or omission relation to the production or supply of food, which is intended } \\
\text { for personal gain or to cause loss to another party. }\end{array}$ \\
\hline $\begin{array}{l}\text { Process manual for the } \\
\text { GFSI benchmarking } \\
\text { process v7.2 (GFSI, } \\
2017 \text { ) }\end{array}$ & $\begin{array}{l}\text { Food fraud: A collective term encompassing the deliberate and intentional substitution, } \\
\text { addition, tampering or misrepresentation of food, food ingredients or food packaging, } \\
\text { labelling, product information or false or misleading statements made about a product } \\
\text { for economic gain that could impact consumer health. }\end{array}$ \\
\hline $\begin{array}{l}\text { Global standards food } \\
\text { safety issue } 8 \\
\text { (BRC, 2018) }\end{array}$ & $\begin{array}{l}\text { Fraudulent and intentional substitution, dilution or addition to a product or raw material, } \\
\text { or misrepresentation of the product or material, for the purpose of financial gain, by } \\
\text { increasing the apparent value of the product or reducing the cost of its production. }\end{array}$ \\
\hline $\begin{array}{l}\text { The EU food fraud } \\
\text { network and the } \\
\text { system for }\end{array}$ & $\begin{array}{l}\text { Food fraud is about intentional actions taken by businesses or individuals for the purpose } \\
\text { of deceiving purchasers and gaining an undue advantage therefrom, in violation of the EU } \\
\text { agri-food chain legislation. These intentional infringements may also constitute a risk to }\end{array}$ \\
\hline
\end{tabular}




\begin{tabular}{ll}
\hline administrative & human, animal or plant health, or to animal welfare or to the environment as regards \\
assistance - food fraud & GMOs and plant protection products. \\
(EC, 2018) & The EU Food Fraud Network refers to four key operative criteria to distinguish whether a \\
& case should be reported as a suspicion of fraud or as a non-compliance: \\
1. Violation of EU law codified in the EU agri-food chain legislation. & 2. Intention \\
& 3. Economic gain \\
& 4. Deception of Customers \\
CWA 17369 (CEN, & $\begin{array}{l}\text { Intentionally causing a mismatch between food product claims and food product } \\
\text { characteristics. }\end{array}$ \\
\hline FSSC 22000 (FSSC, & A collective term encompassing the deliberate and intentional substitution, addition, \\
tamp) & $\begin{array}{l}\text { product information or false or misleading statements made about a product for } \\
\text { economic gain that could impact consumer health (GFSI v7.2:2018). }\end{array}$
\end{tabular}

132

\section{Defining economically motivated adulteration (EMA)}

In some instances, the term EMA has been used interchangeably with food fraud (Everstine, Spink \& Kennedy, 2013; CRS, 2013). Alternately, EMA has been classified as a subcategory of food fraud (Spink \& Harte, 2008; FDA, 2009; Spink 2009; Spink \& Moyer, 2011; van Ruth, Huisman \& Luniong, 2017; Galvin-King, Haughey \& Elliott, 2018). The FDA defined EMA as "fraudulent, intentional substitution or addition of a substance in a product for the purpose of increasing the apparent value of the product or reducing the cost of its production, i.e., for economic gain." The FDA noted that "EMA includes dilution of products with increased quantities of an already-present substance (e.g., increasing inactive ingredients of a drug with a resulting reduction in strength of the finished product, or watering down of juice) to the extent that such dilution poses a known or possible health risk to consumers, as well as the addition or substitution of substances in order to mask dilution" (FDA, 2009). More recently, EMA has been called a "substance of economic gain with potential health risk" (Spink et al., 2019a). Cruse has defined it as "an intentional change in a food product that a consumer is unaware of for economic gain" (Cruse, 2019). Cruse also noted that there is little distinction between EMA and food fraud. Definitions found in this literature review indicate EMA has become near synonymous with the term food fraud. 


\section{Defining food authenticity}

151

152

153

154

155

156

Food authenticity is defined as food being authentic (CEN, 2019). Authentic food is described as a "match between the food product characteristics and the corresponding food product claims" (CEN, 2019). In short, food is authentic when, "food is what it says it is" (DEFRA, 2014; Spink et al., 2019a). The Elliott Review expands on this definition by stating that, "food authenticity is about ensuring that food offered for sale or sold is of nature, substance, and quality expected by the purchaser (Section 14 Food Safety Act 1990)." (DEFRA, 2014). Food authenticity is referred to as a state rather than an act. Therefore, no motivation or intention has been described in literature. Hence, food authenticity is not an intentional or unintentional act, such as food quality or food fraud, but rather is affect by both intentional and unintentional doings.

\section{Defining food integrity}

Food integrity had been defined by the EU Food Integrity Project (2017) as, "the state of being whole, entire, or undiminished or in perfect condition." This project regards integrity as going beyond food fraud, including aspects of food such as the safety and quality of the product (EU FIP, 2017). Similarly, the Elliott Review states that food integrity is defined by food that is, "not only safe and of the nature, substance and quality expected by the purchaser but also captures other aspects of food production, such as the way it has been sourced, procured and distributed and being honest about those elements to consumers." (DEFRA, 2014). Manning (2016) expands on the definition given in the Elliott Review, and describes four types of food integrity issues: (1) product integrity (authenticity) - the inherent quality attribute of totality or completeness; (2) process integrity the activities undertaken to produce the food item encompassing the design, assurance, monitoring 
and verification of processes within the product life-cycle to ensure that they remain authentic and intact; (3) people integrity - described as the honesty and morals exhibited by an individual and (4) data integrity - information accompanying the food item throughout the supply chain that is the consistency and accuracy of data through the food product life-cycle. Broadly stated, Manning (2016) would argue that food integrity would include all aspects of the food product, if the people producing the product were treated ethically, if all data and traceability are accurate, and if processes follow the legal standard and adherence to any claims made. While Spink et al. (2019a) have summarized food integrity as "the product is of the specification defined such as quality and label claims" (EU FIP, 2017).

\section{Defining food crime}

Van Ruth et al. (2018) states that "all food fraud is a form of criminal behaviour no matter the definition of crime," asking the question, whether the terms food fraud and food crime are synonymous? According to Kulling et al. (2019), the term food crime is a form of deceptive criminal behaviour identical to the term food fraud. Likewise, the United Kingdom (UK) National Food Crime Unit (NFCU) (2019) states that food crime "is serious fraud that impacts the safety or the authenticity of food, drink, or animal feed. It can be seriously harmful to consumers, food businesses, and the wider food industry". This definition is vague as is does not clarify what constitutes as 'seriously harmful'. NFCU does go on to give examples of food crime as the "use of stolen food in the supply chain, unlawful slaughter, diversion of unsafe food, adulteration, substitution or misrepresentation of food, and document fraud" (NFCU, 2019). However, all examples given here, could also be examples of food fraud. Therefore, food crime may be described as a subset of food fraud. Spink et al. (2019b) gave two definitions of food crime which are " the violation of a criminal statute using food," and a "serious food fraud incident" (Manning \& 
Soon, 2016; Spink et al., 2019a). Again, these definitions do not clarify how food crime and food fraud differ. However, a violation of criminal statute using food could include the use of food to cause harm, which would not be a subset of food fraud as food fraud has been defined as an act motivated be economic gain (section 4). A distinction is made by Spink et al. (2019a), where food crime is defined as "all types of food fraud which is conducted a large scale." More specifically, this publication states that, "Food fraud becomes food crime when the scale and potential impact of the activity is considered to be serious. This might mean that the criminal activity has cross-regional, national or international reach, that there is a significant risk to public safety, or that there is a substantial financial loss to consumers or businesses." (Spink et al., 2019a). Elliott Review defines food crime stating, "Food fraud becomes food crime when it no longer involves random acts by 'rogues' within the food industry but becomes an organized activity by groups which knowingly set out to deceive, and or injure, those purchasing food" (DEFRA 2014). Definitions found in this review described food crime as both a subset of food fraud that occurs on a large scale and the use of food in criminal acts intended to harm.

\section{Food defense, food safety, food quality and food fraud}

Other terms that may further complicate the understanding of food fraud are: food defense, food safety, and food quality. The main differences between these terms is the intention, whether the act was intentional or unintentional, and the motivation, whether the act is for economic gain or intends to harm to public health, the economy, or create terror (Spink \& Moyer, 2011). The intention and motivation of food fraud, food defense, food safety and food quality are illustrated in Spink and Moyers' food protection risk matrix seen below (Figure 1). 
221

\section{Motivation}

Gain : Economic

Harm:

Public Health, Economic, or Terror

Manning and Soon (2016) defined food defense as the active steps taken, i.e., the procedures, processes, and countermeasures used to achieve product safety in response to intentional acts of adulteration meant to cause harm. Similarly, the Global Food Safety Initiative (GFSI) describes food defense as procedures adapted to ensure the safety of products' intentional malicious attack, malicious tampering, or terrorism (BRC, 2018; GFSI, 2014; GFSI, 2017; Manning, 2019). While PAS 96: 2017 defines food defense as procedures that protect food and drinks form "maliciously and ideologically motivated attack," which leads to contamination of a product or supply disruptions as food defense. The US Food and Drug Administration (FDA) describes food defense as "the effort to protect food from intentional acts of adulteration where there is an intent to cause wide-scale public health harm." (FDA, 2018 as seen in Manning, 2019). All definition agrees that food defense is countermeasures to protect against act using food which intend harm. However, neither Manning and Soon (2016), PAS 96:2017 nor GFSI state that harms must be widespread as specified in US regulations. The principal differences between food fraud and food defense are that in food fraud are acts of adulterations that do not intend to harm and are motivated by greed, while food defense protects against acts that intend to harm (GFSI, 2017). Acts that intend harm could be an act of food crime (seen in section 6) or food terrorism, a subcategory of bioterrorism which is defined by the World Health Organization (WHO) as, "an act or threat of deliberate contamination of food for 
human consumption with chemical, biological or radio-nuclear agents for the purpose of causing injury or death to civilian populations and/or disrupting social, economic or political stability" (WHO, 2002). Although food defense acts against food terrorism, the terms are often used interchangeably.

The GFSI and the Food and Agriculture Organization of the United Nations (FAO) define food safety as an, "assurance food will not cause harm to the consumer which is prepared and/or eaten according to its intended use" (BRC, 2018; FAO, 2017). Food safety issues are described as unintentional contamination of food that makes food injurious to health (Manning \& Soon, 2016). Unlike food fraud and food defense, food safety issues are unintentional. Nevertheless, intentional acts, such as food fraud and food defense, may create food safety issues (Spink, 2019).

As in the case of food safety, food quality issues are unintentional that can be affected by intentional doings. The FAO states that food quality "includes all the attributes that influence a product's value to the consumer. This includes negative attributes such as spoilage, contamination with filth, discoloration, off-odours and positive attributes such as the origin, colour, flavour, texture and processing method of the food" (FAO, 2017; Spink et al., 2019). This definition has been summarized by Manning and Soon (2016) as the "deliverability of attributes that influence a products value to a consumer". Both definitions agree that food quality refers to attributes that affect the acceptability of products and brand equity. Although food quality issues are not the same as food safety issues, food quality may affect food safety (Spink and Moyer, 2011).

\section{Understating interactions in terminology}

Overlapping terminology associated with food integrity, food authenticity, food fraud, food defense, food safety, food quality and food crime creates confusion. Figure $\mathbf{2}$ adapted from Spink and Moyer 
262 (2011) and Manning and Soon (2016) illustrates how the terms interact with each other. This

263 modification includes food integrity, which was not included in previous publications. Food integrity

264 is shown as an overarching term that is related to intentional and unintentional acts that includes

265 food fraud and the safety, quality, and authenticity of a food product. It also includes the way a

266 product was produced and procured; therefore, if a product was produced in an unethical or illegal

267 way, product integrity is lost. Food integrity is compromised if an intentional or unintentional issue

268 occurs. Issues that can occur in the form of contaminants are any substance not intentionally added

269 to food, which is present in food as a result of production; or adulterants which are any substance

270 intentionally added to food, which is not present in food as a result of production (Spink, 2019).

271 Modifications also include food authenticity centered around whether a product was adulterated or

272 contaminated, in intentional or unintentional acts. Intentional acts fall under the definitions of food

273 fraud and food defense. However, the motivation behind food fraud and food defense differs. Acts

274 of food crime such as food fraud do not intend to cause harm but is committed on a large scale. 
278

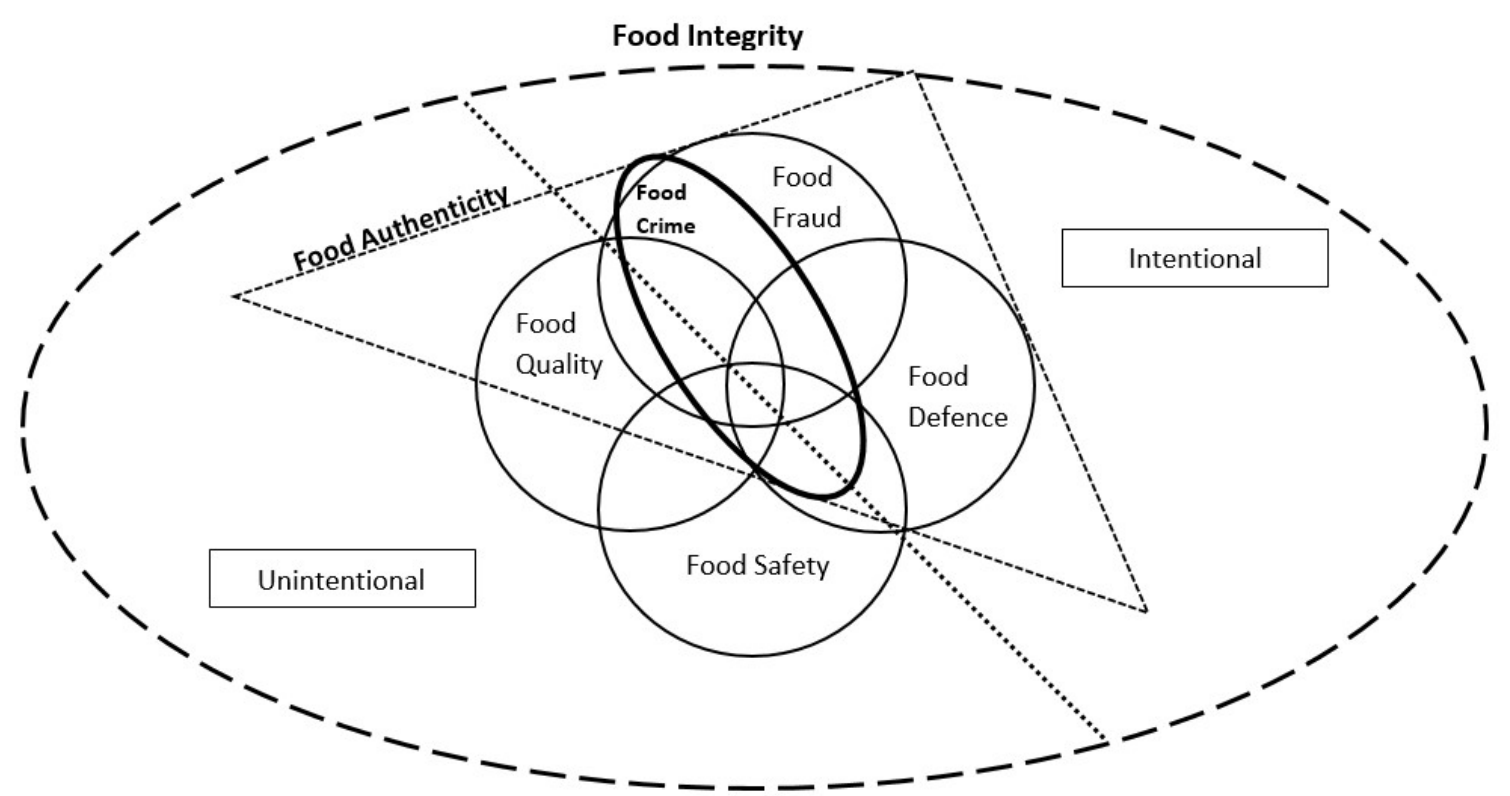

Food fraud has been further categorised into types of fraud (GAO, 2009; Spink \& Moyer, 2011; NFCU, 2019a). Determining types of food fraud helps to decide how fraud might occur in the food supply. The most frequently referred to types of food fraud found in this data were defined by Spink and Moyer (2011), Table 4. Spink and Moyer's (2011) fraud types have been cited 377 times (at time of manuscript submission) and has been cited in numerous articles found in literature searches conducted for this review (Cawthorn, Stainman \& Hoffman 2013; Galvin-King, Haughey \& Elliott, 2018; Manning, 2016; Manning \& Soon, 2014; Sentandreu \&Sentandreu 2014; Soon et al., 2019). These and other types of food fraud found through literature searches in this review are outlined in Table 3. All of the listed types of food fraud describe those which could occur in any food supply chain. 


\begin{tabular}{|c|c|c|c|c|c|c|c|c|c|c|c|}
\hline & $\begin{array}{l}\text { GAO, } \\
2009\end{array}$ & $\begin{array}{c}\text { Spink \& } \\
\text { Moyer, } \\
2011\end{array}$ & $\begin{array}{l}\text { Manning } \\
\text { and Soon, } \\
2016\end{array}$ & $\begin{array}{l}\text { Manning, } \\
2016\end{array}$ & $\begin{array}{c}\text { Spink, } \\
\text { Moyer } \\
\text { and } \\
\text { Whelan, } \\
2016\end{array}$ & $\begin{array}{l}\text { GFSI, } \\
2017\end{array}$ & $\begin{array}{c}\text { RASFF } \\
\text { (Bouzembrak et } \\
\text { al., 2018) }\end{array}$ & $\begin{array}{l}\text { HorizonScan } \\
\text { (Bouzembrak et } \\
\text { al., 2018) }\end{array}$ & $\begin{array}{l}\text { Manning } \\
\text { and Soon, } \\
2019\end{array}$ & $\begin{array}{l}\text { CWA } \\
17369 \\
\text { (CEN, } \\
2019 \text { ) }\end{array}$ & $\begin{array}{l}\text { NFCU, } \\
2019 a\end{array}$ \\
\hline Addition & & & & $x$ & $\mathrm{x}$ & & & & $x$ & $x$ & \\
\hline $\begin{array}{l}\text { Additional of illegal/unapproved } \\
\text { or undeclared additives }\end{array}$ & & & & $x$ & $x$ & & & & & & \\
\hline Adulterant-substances & & & & $\mathrm{x}$ & $x$ & & & & & & \\
\hline Adulteration & & $\mathrm{x}$ & $\mathrm{x}$ & & & & & $\mathrm{x}$ & $\mathrm{x}$ & $\mathrm{x}$ & $\mathrm{x}$ \\
\hline $\begin{array}{l}\text { Breaches of Protected } \\
\text { Designation of Origin (PDO), } \\
\text { Protected Geographical } \\
\text { Indication (PGI) and Traditional } \\
\text { Specialties Guaranteed (TSG) } \\
\text { Requirements }\end{array}$ & & & & $\mathrm{x}$ & $\mathrm{x}$ & & & & & & \\
\hline Claim violation & & & & & & & & & $\mathrm{x}$ & $x$ & \\
\hline Concealment & & & & $x$ & $x$ & $\mathrm{x}$ & & & & & \\
\hline Counterfit & & $\mathrm{x}$ & $\mathrm{x}$ & & & $x$ & & $\mathrm{x}$ & $\mathrm{x}$ & & \\
\hline Dilution & & & & $x$ & $x$ & $x$ & & & & $x$ & \\
\hline Diversion & & $\mathrm{X}$ & $x$ & $\mathrm{x}$ & $x$ & $x$ & & $\mathrm{x}$ & $\mathrm{x}$ & & \\
\hline Document fraud & & & & & & & & & & & $x$ \\
\hline Duplication & & & & & & & & & $\mathrm{x}$ & & \\
\hline Expiration date & & & & & & & $x$ & & & & \\
\hline Extension & & & & $\mathrm{x}$ & $\mathrm{x}$ & & & & & & \\
\hline
\end{tabular}


False declaration

of - geographical region,

species, botanical or varietal

origin, masking, introduction of

animal by-products to the food

chain

\section{False health claims}

False or misleading statements

made about a product for

economic gain

Grey market production

Illegal and unapproved slaughter

Illegal importation

Illegal processing

Illegal sale of unauthorized food

supplement

Improper, expired, fraudulent or

missing common entry

documents

Improper, fraudulent, missing or absent health certificates

Intellectual property rights

counterfeiting

Introduction of food waste to the

food supply chain

Malicious poisoning, bioterrorism

or sabotage

Misbranding

Misdescription

Mislabelling

Misleading

indications(works/pictures)
$\mathrm{X}$

$\mathrm{X}$

$\mathrm{X}$

$X$

$X$

$X$

$x \quad x$

$\mathrm{X} \quad \mathrm{X}$

$x$

$\mathrm{X}$

$\mathrm{X} \quad \mathrm{X}$

$x+x$

$\mathrm{X} \quad \mathrm{X}$

$X$

$x \quad x \quad x \quad x$

$\mathrm{X}$

$x$ 
Misleading use on product of

quality assurance scheme

branding which the producer is

not accredited to

Misrepresentation

Mixing of adulterants

Modification

Non-disclosure of changes made

to the nature

Over-run

Over-treating

Packaging size

Product tampering

Production from unapproved and

unsuitable food premises

Records tampering

Removal

Replacement

Selling non organic food as

organic

Short weighing $\quad \mathrm{X}$

Simulation $\quad X$

Smuggling

Species Substitution

$X$

Substance and quality of a

product

Substitution

Tampering

Tax avoidance/Gray market

product

Theft

$\mathrm{X}$

$x \quad x$

$\mathrm{X}$

$x \quad x$

$\begin{array}{ll}x & x \\ x & x\end{array}$

$x$

$x$
$x$
$x$
$x$

$\begin{array}{ll}X & X \\ X & X\end{array}$

$X$
$X$

$X$
$X$

X

$x \quad x$

$\begin{array}{llll}x & x & x & x \\ x & x & x\end{array}$

$\begin{array}{ll}X & X \\ X & X\end{array}$

$x$

$\mathrm{X}$

$\begin{array}{lll}X & X & X \\ X & X & X \\ X & X & X\end{array}$

$X$


Transhipment

$\mathrm{X}$

$\mathrm{X}$

Unapproved enhancements

$\mathrm{X}$

Unapproved pesticides

X

Unapproved processes

X

Use of illegal food contact

X

material and packaging

X

X

Waste diversion 
The specificity of food fraud types given in publications shown in Table $\mathbf{3}$ varies between being very generalized to extremely precise. The GAO (2009) defines five general types of food fraud. All other publications have expanded from this. For example, Spink, Moyer, and Whelan (2016) described 38 types of food fraud, which they state could be summarized into the seven types given by Spink and Moyer (2011). This same range is seen in the most recent publications; Manning and Soon (2019) are very specific and described 20 types of food fraud, while the NFCU (2019) is more generalized and described seven types of fraud. It seems researchers are still determining the level of specificity needed to best communicate how fraud can be committed in food supply chains. By being overly specific researchers may leave gaps and fraud types may be left out, however if types are too general there may be ambiguity concerning how a fraud type is defined and how it appears in the food supply chain as indicated in sections 2-6 and can lead to inconstant terms.

As seen, types of fraud presented by researchers are not consistent; however, it appears that researchers have built on previous research. For example, types of fraud used in HorizonScan (Bouzembrak et al., 2018) are the same as those defined by Manning and Soon (2016), excluding "Packing size." Manning and Soon (2016) agreed with the seven types of fraud described by Spink and Moyer (2011) with the addition of "Malicious poisoning, bioterrorism or sabotage," "Misleading indications (works/pictures)," and "Package size." Then again in 2016, types of fraud described by Manning are almost the same as Spink, Moyer, and Whelan (2016) but Spink, Moyer, and Whelan (2016) did not include "Malicious poisoning, bioterrorism or sabotage" and "Misleading indications (works/pictures)." In 2017 the GFSI described nine broad fraud types using language, which seemingly tried to include the list of types described by Manning and Soon and Spink, Moyer, and Whelan in 2016-again showing a struggle between over-generalizing and over-specifying types of fraud. 
As researchers specify and generalize types of fraud, terminology used may be the same yet definitions of these terms may differ. For example, eight of the ten document sources name tampering as a type of food fraud. The European Committee for Standardization (CEN) (2019) is the only source which described two kinds of tampering by differencing between record tampering, that is the "deliberate changing of explicit food products claims so that they do no longer match the known characteristics", and product tampering; "the deliberate changing of food product characteristics so that they no longer match the implicit or explicit claims associated with the product." Spink and Moyer (2011) do not distinguish between record and product tampering. They define tampering as "Legitimate product and packaging used in a fraudulent way" (Spink \& Moyer, 2011). This definition is comparable to the CEN definition of record tampering, but not product tampering. Instead of product tampering, Spink and Moyer (2011) use the term adulteration to describe when "a component of the finished product is fraudulent." The CEN (2019) notes that, in some cases, adulteration "means the same things as" how they define tampering. However, the CEN (2019) differentiates the two by stating, "adulteration according to most definitions includes the addition of a foreign or inferior substance to the food product, whereas tampering as defined here can also include subjecting the product to an undeclared process, or removing something that should have been present in the product." To further complicate types of fraud, the NFCU (2019) doesn't use the term tampering or record tampering, but instead used the title 'misrepresentation' to define the act of "marketing or labelling a product to wrongly portray its quality, safety, origin or freshness."

Confusion can be caused by multiple types of fraud described and differing terminology used. A number of publications have created images to illustrate a hierarchy of terms and how fraud types interact to create more clarity. CEN (2019) describes product tampering (defined above) as a type of food fraud. It then describes adulteration, "intentionally adding an unapproved, undeclared, or inactive ingredient to the food product, or substituting a declared ingredient with another 
ingredient," as a type of product tampering. Following on it states that adulteration includes all forms of addition, that is "intentionally adding an unapproved or undeclared ingredient to the food product"; dilution, "intentionally increasing the quality of an inactive or already-present substance," and substitution, "intentionally replacing a declared ingredient in a food product with another ingredient" (CEN, 2019). To help clarify the interactions between fraud types, the CEN (2019) created a hierarchy of terms (Figure 3). Similarly, Ballin (2010) shows four main types of fraud in meat (meat origin, meat substitution, meat processing treatment, and non-meat ingredient additives), then sub-divided these into 20 types of food fraud (Figure 4). These figures provide a visual representation of interactions between types of food fraud, which can aid in creating a better understanding.

Figure 3. Hierarchy of terms and definitions (CEN, 2019)

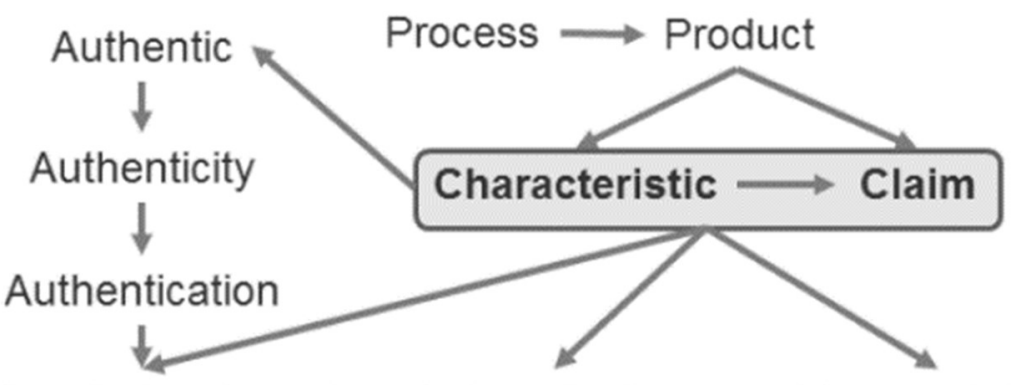
characteristics

Authentication based Authentication on analysis of product based on analysis of recorded data

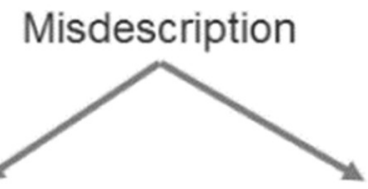
Food fraud

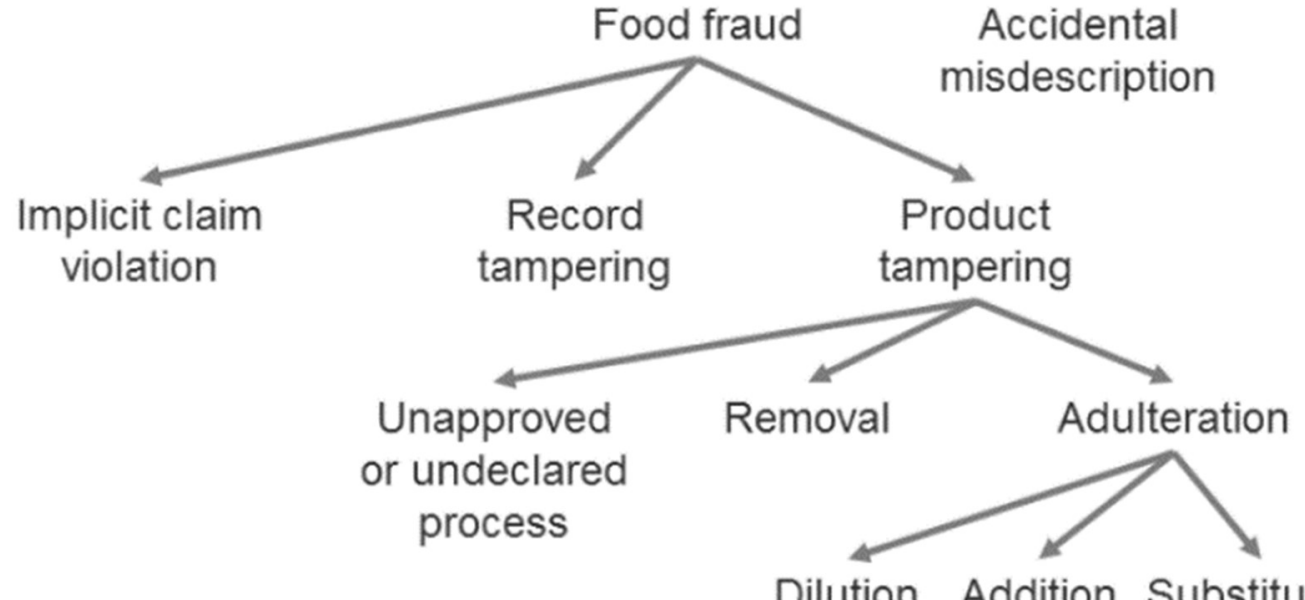




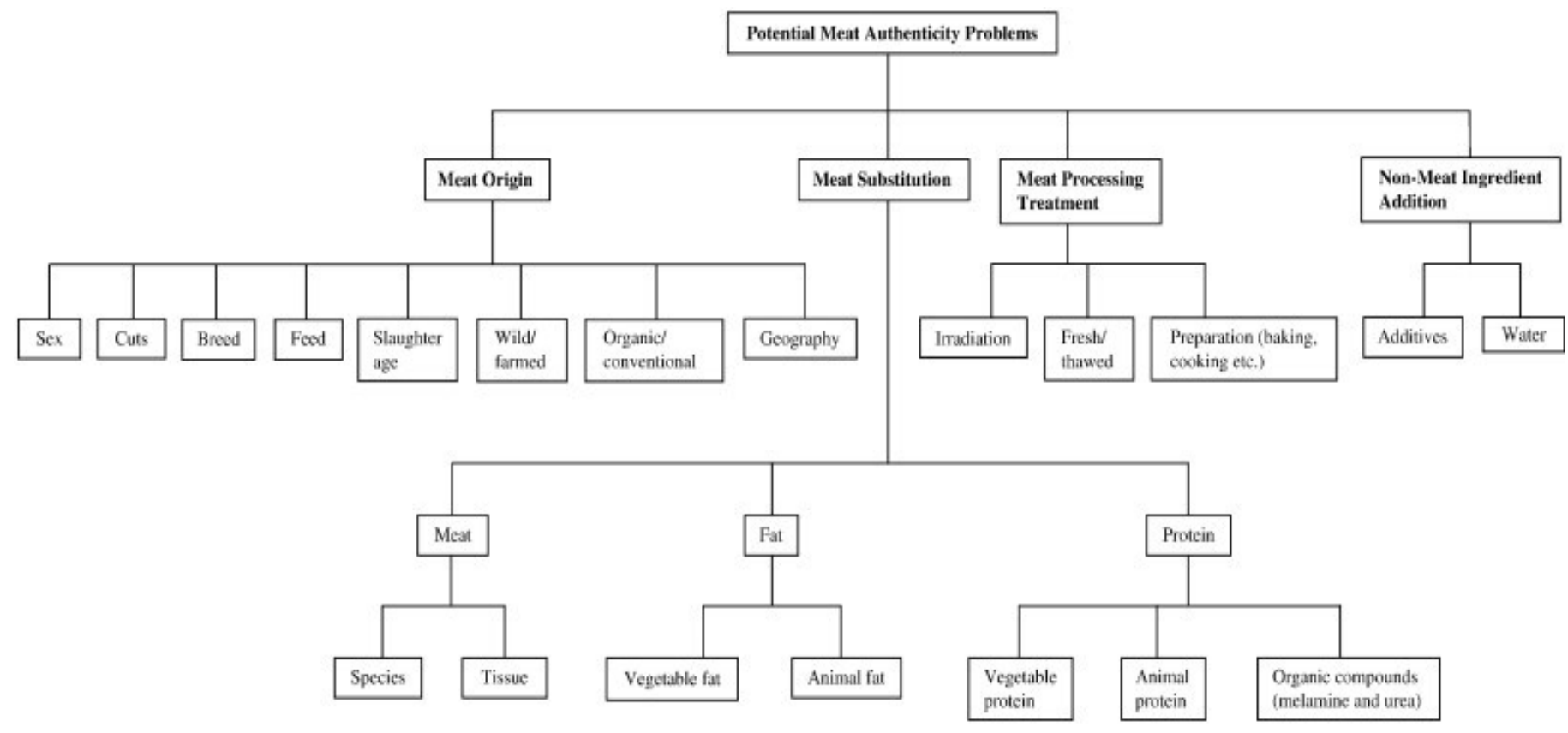

359

360 The publications in Table 3 list types of fraud which can occur in all kinds of food supply chains,

361 alternatively Ballin (2010) determined types of food fraud specific to meat (Figure 3). Ballin (2010)

362 shows four main types of fraud in meat, which were then sub-divided into 20 types. By specifying

363 types of fraud to a particular supply chain the author was able to more accurately communicate

364 different types of food fraud which may be seen in this sector.

366 Determining types of food fraud can help create a better understanding of how fraud occurs and aid

367 communication. Identifying types of food fraud is an ongoing effort; recent research building on

368 previous publications to create clear descriptions of how fraud is occurring. Currently, there is a lack varying meanings. 
Lack of consistent definitions for food fraud in the EU is a barrier to creating legislation that influences the creation of a collective approach in addressing food fraud (Kowalska, Soon \& Manning, 2019). Therefore, food fraud is not addressed in any single EU law but is indirectly addressed through the violation of food law (Spink et al., 2019c). This creates an obstacle in combatting food fraud. Depending on the type of fraud and the type of product that is involved in the fraudulent act, different legislation relates to food fraud, including:

- Regulation (EC) No 178/2002 on general food law on imports and exports, traceability,

Another challenge in the creation of food fraud legislation and regulations is that food fraud acts are committed outside of authorized or legitimate supply chains (Primrose, Woolfe \& Rollinson, 2010). Therefore, to help defend against food fraud, the EU has established the EU Food Fraud Network, which empowers member states to exchange information and to collaborate voluntarily in matters 
of food fraud (EC, 2020). Furthermore, member states have individually set up regulatory bodies to defend against food fraud. An example of this is the NFCU established in the UK in 2015 in response to the 2013 horse meat scandal as a law enforcement arm of the Food Standards Agency (FSA) focusing on food crime (NFCU, 2019b).

\section{Food fraud mitigation and prevention}

In addition to understanding food fraud, this review aimed to review prevention and mitigation countermeasures used to protect the food supply chain from food fraud (Spink et al., 2017). Prevention and mitigation both aim to control food fraud. Mitigation assumes food fraud events will frequently occur and focus on trying to mitigate or reduce the negative consequence (Spink et al., 2017; 2019a). Prevention assumes that the root cause of the event could be eliminated or at least significantly reduced in the likelihood of occurrence (Spink et al., 2017; 2019a). Food fraud prevention aims at reducing food fraud before it occurs (Moyer, DeVries, \& Spink, 2017). Achieving food fraud prevention and mitigation depends on identifying, reducing or eliminating vulnerability. A vulnerability is a weakness or flaw that creates opportunities; or susceptibility to the system for food fraud (Spink et al., 2017). This differs from risk which is the potential for an unwanted outcome resulting from an incident, event, occurrence, as determined by its likelihood and the associated consequence (Spink et al., 2019a).

The food industry is liable for the quality and safety of its products and therefore is also liable for food fraud even if they were a victim of the fraud themselves (Wisniewski \& Buschulte, 2019). Therefore, the responsibility of food fraud mitigation and prevention primarily falls on the food industry (Wisniewski \& Buschulte, 2019). The food industry includes primary processers who turn raw materials into a form which is safe for human consumption, manufacturers who produce products into raw material or components into retail units or supplier products, retailers who sell 
product to the consumer and any business or operator who carries out the processing, manufacturing, packaging, storage, transports, import, distribution or sale of food (Nestle, 2016; BRC, 2018; EIT Food and Queens University Belfast, 2020). Lack of understanding of where fraud may be occurring and what types of fraud are happening has left the food industry vulnerable (Spink et al., 2019). Van Ruth, Huisman, and Luning (2017) assess a company's food fraud vulnerability through determining the motivation of fraudsters, opportunity for fraud, and control measures to detect fraud. The food industry can use this knowledge to look out for economic drivers and business culture, which may motive fraud, identify areas of opportunity, and implement measures to detect incoming fraud. Furthermore, van Ruth (2018) describes 50 specific fraud factors which can help a company determine vulnerability, such as the complexity of adulteration of raw materials, supply, and pricing raw material and tracking and tracing system supplier. These factors can help a company assess its vulnerability and the vulnerability of different commodities within their supply base.

Table 5 lists 12 guidance documents designed to aid the prevention and mitigation of food fraud. Most of these documents are aimed at large business food operators, which are organizations that carrying out activities related to processing, manufacture, packaging, storage, transportation, import and distribution of food (Nestle, 2016). These types of businesses have staff and resources available to follow the advice given in the guidance documents found in this review. Food authenticity five steps to help protect your business from food fraud did offer a number for small businesses to contact and get advice on fraud mitigation (FDF, 2014). Still, there is a gap in knowledge and available support for small producers, manufactures and retailers who may not have the resource available to dedicate to practices shared in the guidance documents below, which leaves the food supply vulnerable to fraud. 
444 Guidance on Authenticity of Herbs and Spices was the only guidance document found which focused

445 on a specific supply chain (FDF, 2016). All others guidance documents provided general direction

446 which could be applied to all supply chains. Tools and concepts given for non-specific supply chains

447 is beneficial as they can be adapted for individual supply chain needs and used for all differencing

448 supply chains. However, there are advantages to having specified information. Even with general

449 tools given business are left with a large amount of work to determine risks and vulnerabilities

450 bespoke to their specific supply chain. Having specified guidance available individual supply chains

451 would provide businesses with more in-depth information and allow for more holistic food

452 prevention and mitigations plans to be developed. For example, Guidance on Authenticity of Herbs

453 and Spices (FDF,2016) includes flow charts and harvest information specific to herbs and spices,

454 allowing companies to take into account risks posed by seasonal changes in supply. 


\begin{tabular}{|c|c|c|c|c|}
\hline Title & Description & $\begin{array}{l}\text { Nature of } \\
\text { Business }\end{array}$ & Supply Chain & Mitigation Measures \\
\hline $\begin{array}{l}\text { Food authenticity five } \\
\text { steps to help protect } \\
\text { your business from food } \\
\text { fraud (FDF, 2014) }\end{array}$ & $\begin{array}{l}\text { This simple guide, which follows on from FDF's } \\
\text { Guide on 'Sustainable Sourcing: Five Steps Towards } \\
\text { Managing Supply Chain Risk', sets out a step-by- } \\
\text { step process to help food and drink manufacturing } \\
\text { businesses of all sizes protect their businesses from } \\
\text { food fraud by helping them to identify, priorities } \\
\text { and manage upstream supply chain food } \\
\text { authenticity risks }\end{array}$ & $\begin{array}{l}\text { Large Scale } \\
\text { Operators }\end{array}$ & $\begin{array}{l}\text { General guidance } \\
\text { for all supply chains }\end{array}$ & $\begin{array}{ll}\checkmark & \text { Map Your Supply Chain } \\
\checkmark & \text { Identify Impacts, Risks and Opportunities } \\
\checkmark & \text { Assess and Priorities Your Findings } \\
\checkmark & \text { Create a Plan of Action } \\
\checkmark & \text { Implement, Track, Review \& Communicate }\end{array}$ \\
\hline $\begin{array}{l}\text { GFSI position on } \\
\text { mitigating the public } \\
\text { health risk of food fraud } \\
\text { (GFSI, 2014) }\end{array}$ & $\begin{array}{l}\text { The GFSI Board decided to follow the } \\
\text { recommendations of the Food Fraud Think Tank and } \\
\text { proposes to incorporate the two food fraud } \\
\text { mitigation steps in the form of two new key } \\
\text { elements in the GFSI Guidance Document to; } \\
\text { 1. Require a company to perform a food fraud } \\
\text { vulnerability assessment } \\
\text { 2. Have a control plan in place. } \\
\text { The vision is that, like the introduction of food } \\
\text { defense into the Guidance document a few years } \\
\text { ago, the mitigation of food fraud and the potential } \\
\text { impact on consumers' health becomes an integral } \\
\text { part of a company's food safety management } \\
\text { system. }\end{array}$ & $\begin{array}{l}\text { Large Scale } \\
\text { Operators }\end{array}$ & $\begin{array}{l}\text { General guidance } \\
\text { for all supply chains }\end{array}$ & $\begin{array}{ll}\checkmark & \text { GFSI position } \\
\checkmark & \text { Proposed key elements for food fraud mitigation }\end{array}$ \\
\hline $\begin{array}{l}\text { Counter Fraud Good } \\
\text { Practice Guide for Food } \\
\text { and Drink Businesses } \\
(\mathrm{ClEH}, 2016)\end{array}$ & $\begin{array}{l}\text { The purpose of this guide is to outline how food and } \\
\text { drink business can apply established counter fraud } \\
\text { good practice to improve fraud resilience and } \\
\text { reduce its financial and reputational cost }\end{array}$ & $\begin{array}{l}\text { Large scale food } \\
\quad \text { operators }\end{array}$ & $\begin{array}{l}\text { General guidance } \\
\text { for all supply chains }\end{array}$ & $\begin{array}{ll}\checkmark & \text { The impact of fraud } \\
\checkmark & \text { Fraud affects food businesses } \\
\checkmark & \text { The advantage of focusing on fraud reliance } \\
\checkmark & \text { The role of government in detecting and addressing } \\
& \text { fraud } \\
\checkmark & \text { The modern strategic approach to counter fraud } \\
\checkmark & \text { Summary of counter fraud good practice } \\
\checkmark & \text { Counter fraud good practice for food and drink } \\
& \text { businesses } \\
\checkmark & \text { Establish the nature and scale of the problem } \\
\checkmark & \text { Develop a strategy } \\
\checkmark & \text { Establish an implementation structure } \\
\checkmark & \text { Design and implement fraud prevention measures } \\
\checkmark & \text { Design and implement fraud detection measures }\end{array}$ \\
\hline
\end{tabular}




\begin{tabular}{|c|c|c|c|c|c|}
\hline & & & & $\checkmark$ & $\begin{array}{l}\text { Design and implement investigative processes } \\
\text { Monitor outcomes }\end{array}$ \\
\hline $\begin{array}{l}\text { Food Fraud Mitigation } \\
\text { Guidance (USP, 2016) }\end{array}$ & $\begin{array}{l}\text { USP's Food Fraud Mitigation Guidance provides a } \\
\text { practical framework to help your organization } \\
\text { develop a system for identifying vulnerabilities in } \\
\text { your ingredient supply chain and developing a } \\
\text { control plan to mitigates risks. }\end{array}$ & $\begin{array}{l}\text { Large scale food } \\
\text { operators }\end{array}$ & $\begin{array}{l}\text { General guidance } \\
\text { for all supply chains }\end{array}$ & $\begin{array}{l}\checkmark \\
\checkmark \\
\checkmark\end{array}$ & $\begin{array}{ll}\text { Terminology } \\
\text { Contributing factors assessment } \\
\circ \quad \text { Supply chain } \\
\circ \quad \text { Audit strategy } \\
\circ \quad \text { Supplier relationship } \\
\circ \quad \text { History of suppliers } \\
\circ \quad \text { Testing frequency } \\
\circ \quad \text { Geopolitical considerations } \\
\circ \quad \text { Fraud history } \\
\circ \quad \text { Economic anomalies } \\
\text { Potential impact assessment } \\
\circ \quad \text { Public health impact } \\
\circ \quad \text { Economic impact } \\
\text { Overall vulnerabilities } \\
\text { Mitigation strategies development }\end{array}$ \\
\hline $\begin{array}{l}\text { Food Fraud Prevention } \\
\text { (Nestle, 2016) }\end{array}$ & $\begin{array}{l}\text { The purpose of this booklet is to guide food } \\
\text { operators through approaches and processes to } \\
\text { improve the resilience of supply chains to food } \\
\text { fraud. It provides guidance on how to assure the } \\
\text { authenticity of food by minimising vulnerability to } \\
\text { fraud and mitigating the consequences of food } \\
\text { fraud. This booklet Describes a process for food } \\
\text { fraud prevention and the principles of the } \\
\text { vulnerability assessment; Outlines measures that } \\
\text { can deter fraudsters, or give early detection of food } \\
\text { fraud and provides sources of information and } \\
\text { intelligence that may help to identify emerging } \\
\text { threats. }\end{array}$ & $\begin{array}{l}\text { Large Scale } \\
\text { Operators }\end{array}$ & $\begin{array}{l}\text { General guidance } \\
\text { for all supply chains }\end{array}$ & $\begin{array}{l}\checkmark \\
\checkmark \\
\checkmark \\
\checkmark \\
\checkmark\end{array}$ & $\begin{array}{l}\text { What is food fraud } \\
\text { Raw Material Specifications } \\
\text { Analytical surveille } \\
\text { Supplier relationship } \\
\text { Supplier audit }\end{array}$ \\
\hline $\begin{array}{l}\text { Food fraud vulnerability } \\
\text { assessment and } \\
\text { mitigation (PwC,2016) }\end{array}$ & $\begin{array}{l}\text { PwC has the expertise in risk assessment, forensic } \\
\text { services, supplier management and internal controls } \\
\text { required to help companies assess their } \\
\text { vulnerability to food fraud, then design and } \\
\text { implement measures to mitigate food fraud risk. } \\
\text { Along with the SAFEE tool PwC has published a sort } \\
\text { mitigation guide offering information on food fraud. }\end{array}$ & $\begin{array}{l}\text { Large Scale } \\
\text { Operators }\end{array}$ & $\begin{array}{l}\text { General guidance } \\
\text { for all supply chains }\end{array}$ & $\begin{array}{l}\checkmark \\
\checkmark \\
\checkmark \\
\checkmark \\
\checkmark \\
\checkmark \\
\checkmark\end{array}$ & $\begin{array}{l}\text { Are you doing enough to prevent food fraud? } \\
\text { A few things you may want to know } \\
\text { Food fraud and food safety: What is the connection? } \\
\text { A science-based framework for understanding food } \\
\text { fraud risk } \\
\text { Opportunities } \\
\text { Motivations } \\
\text { Control Measures }\end{array}$ \\
\hline
\end{tabular}

Page 29 of 49 
$\checkmark \quad$ The war on food fraud

$\checkmark$ Ready to get started a few things you should know

$\checkmark$ Food fraud Challenges

$\checkmark \quad$ New GFSI food fraud requirements

$\checkmark \quad$ We can provide greater insight and management of fraud risk

Food Supply Chain Vulnerability: A Ti

whitepaper in

partnership with RQA

Group (RQA Group,2016)
Vulnerability of the food supply chain is one of the

hottest topics in the international food industry.

Those vulnerabilities are not limited to breaches of

physical security, theft and malicious contamination

by ideologues, extortionists, criminals or terrorists.

In this whitepaper, Ti's CEO, Professor John

Manners-Bell, and Managing Director, RQA Group,

Vince Shiers Ph.D., offers insight into the

vulnerability of the food supply chain by highlighting the threats and offering analysis of the best practice for securing the supply chain.

\section{Guidance on}

Authenticity of Herbs

and Spices: Industry best

practice on assessing and

protecting culinary dried

herbs and spices (FDF,
This guidance was developed by a Joint Industry

Working Group comprised of representatives of the

British Retail Consortium, Food and Drink

Federation and Seasoning and Spice Association, in

liaison with the Food Standards Agency and Food

Standards Scotland to provide Industry Best Practice

Guidance on vulnerability assessment for culinary dried herbs and spices (including blends), in order to mitigate against potential adulteration and substitution.
Large scale food General guidance operators for all supply chains $\checkmark \quad$ Threats to the food supply chain

- Malicious tampering

- Theft

- Food Safety and temperature control

$\checkmark$ Securing the supply chain
Large scale food operators
Herbs and spices

$\checkmark \quad$ Decision tree to protect herbs and spices against supply chain vulnerabilities

$\checkmark$ Product Specifications

$\checkmark$ Supplier Assurance

$\checkmark$ Product type

$\checkmark \quad$ Knowing your Market Understanding Vulnerabilities in Your Supply Chain

$\checkmark \quad$ Verification and detection measures

$\checkmark$ Sampling and inspection programmes

$\checkmark$ Selection a Test Method and Laboratory

$\checkmark$ Supply Chain Verification Measures

$\checkmark$ Receipt of Material

Devising Testing Strategy

$\checkmark$ Types and Methods of Adulteration

$\checkmark \quad$ Generic Supply Map for Herbs and Spices with Examples of Fraud Vulnerabilities

$\checkmark$ Typical Harvest Charts

Working Together to

Tackle the Threat From

Food Crime (NFCU, 2016)
The UK National Food Crime Unit (NFCU) has

produced a guide for working in partnership with

the food industry to respond to the challenge of

food crime. The guide explains the role of the NFCU in the fight against food crime, how the NFCU can

support industry, and how in turn industry can
Large Scale General guidance

Operators

for all supply chains $\checkmark$ What is the National Food Crime Unit?

$\checkmark$ What is the Threat from Food Crime?

$\checkmark$ Tackling Food Crime, a Shared Objective

$\checkmark$ Looking After Your Information 
support the NFCU to enhance the UK's resilience

and response to food crime in its many forms.

\begin{tabular}{|c|c|c|c|c|c|}
\hline $\begin{array}{l}\text { PAS 96:2017, Guide to } \\
\text { protecting and defending } \\
\text { food and drink from } \\
\text { deliberate attack (BSI, } \\
\text { 2017) }\end{array}$ & $\begin{array}{l}\text { The purpose of PAS } 96 \text { is to guide food businesses } \\
\text { through approaches and procedures to improve } \\
\text { resilience of the supply chain form fraud and other } \\
\text { forms of attach. PAS aims to assure food } \\
\text { authenticity and safety, and minimize chance of } \\
\text { attack. }\end{array}$ & $\begin{array}{l}\text { Large Scale } \\
\text { Operators }\end{array}$ & $\begin{array}{l}\text { General guidance } \\
\text { for all supply chains }\end{array}$ & $\begin{array}{l}\checkmark \\
\checkmark \\
\checkmark \\
\checkmark \\
\checkmark \\
\checkmark \\
\checkmark \\
\checkmark \\
\checkmark\end{array}$ & $\begin{array}{l}\text { Terms and definitions } \\
\text { Types of threats } \\
\text { Understanding the attacker } \\
\text { Threat Assessment Critical Control Point (TACCP) } \\
\text { Assessment } \\
\text { Critical Controls } \\
\text { Response to an incident } \\
\text { Review of food protection arrangements } \\
\text { TACCP Case Studies }\end{array}$ \\
\hline $\begin{array}{l}\text { Guidance on Food fraud } \\
\text { Mitigation (FSSC 22000, } \\
\text { 2018) }\end{array}$ & $\begin{array}{l}\text { Following the GFSI benchmarking requirements, } \\
\text { FSSC } 22000 \text { has introduced a chapter on Food fraud } \\
\text { mitigation in the latest version of the Scheme ( } 44.1 \text { ). } \\
\text { This has become mandatory from January 1, } 2018 \\
\text { and includes requirements for a Food fraud } \\
\text { Vulnerability Assessment and a Food fraud } \\
\text { Prevention Plan applicable to all products. }\end{array}$ & $\begin{array}{l}\text { Large Scale } \\
\text { Operators }\end{array}$ & $\begin{array}{l}\text { General guidance } \\
\text { for all supply chains }\end{array}$ & $\begin{array}{l}\checkmark \\
\checkmark \\
\checkmark \\
\checkmark \\
\checkmark\end{array}$ & $\begin{array}{l}\text { Definition } \\
\text { FSSC } 22000 \text { scheme Requirements } \\
\text { Food fraud Mitigation Team Training } \\
\text { Implementation } \\
\text { Auditing }\end{array}$ \\
\hline $\begin{array}{l}\text { Tackling food fraud } \\
\text { through food safety } \\
\text { management systems } \\
\text { (GFSI, 2018) }\end{array}$ & $\begin{array}{l}\text { Builds off GFSI, 2014. To offer more insight on types } \\
\text { of food fraud and food fraud vulnerability. }\end{array}$ & $\begin{array}{l}\text { Large Scale } \\
\text { Operators }\end{array}$ & $\begin{array}{l}\text { General guidance } \\
\text { for all supply chains }\end{array}$ & $\begin{array}{l}\checkmark \\
\checkmark \\
\checkmark \\
\checkmark \\
\checkmark\end{array}$ & $\begin{array}{l}\text { What is food fraud and is it a challenge for food } \\
\text { safety and management systems } \\
\text { The GFSI requirements on food fraud } \\
\text { The implementation } \\
\text { Auditing a vulnerability assessment and a food fraud } \\
\text { mitigation plan } \\
\text { Detail of types of fraud, and examples }\end{array}$ \\
\hline
\end{tabular}


Although, all documents listed in Table 5 provide beneficial information on food fraud prevention and mitigation for food business operators, guidance is still lacking. Many of the documents give companies the same advice digested and presented in various ways. The core advice given include: (i) the development a system to check and approve suppliers, (ii) supplier audits, (iii) creating open and transport relationships with suppliers, (ix) horizon scanning, the act of looking for and analysing external threats and opportunities that will emerge, including economic anomalies, geographical considerations, political unrest and climate change (Food Fraud Advisors, 2020); (x) identification of vulnerabilities, and (xi) risk assessment. All of the above advice is agreed as being essential in food fraud prevention and mitigation plans. However, each document offers bespoke information. PAS 96:2017 is an extensive document which offers thorough guidance, however, it focuses on food defense rather than food fraud (BSI, 2017). Still PAS 96:2017 offers detailed plans for vulnerability identification and prioritization (BSI, 2017). Nestlé's Food Fraud Prevention document focuses on determining the inherit vulnerabilities of a raw material, supplier relationship and supplier audit, but does not provide specific information about how to determine raw material vulnerabilities or information on developing prevention, mitigation or detection plans (BSI, 2017). Nestlé's Food Fraud Prevention plan does note the importance of self- assessment and the importance of companies working proactively toward food fraud mitigation (Nestle, 2016). Food Supply Chain Vulnerability: A Ti whitepaper in partnership with RQA Group gives ideas on what threats and vulneraries in the supply chain might look like though the use of cases studies, and provides questions that businesses should ask to ensure they have proper food fraud mitigation measures in place (RQA Group,2016). Food Fraud Mitigation Guidance provided by the USP provides factors which contribute to vulnerably as well as matrixes to determine the contribution to vulnerability which applies to each factor, an unlike many of the other documents Food Fraud Mitigation Guidance takes testing frequency into account when assessing vulnerability (FSSC 22000, 2018). Guidance on Food Fraud Mitigation from FSSC 22000 (2018) focuses on conducting a food fraud vulnerability assessment and auditing. Additionally, this document states the importance of a 
business establishing a food fraud mitigation team, to manage and update mitigation plans. While these guidance documents offer generalized insight on food fraud mitigation and prevention, they do not offer specific insight on food fraud to individual product supply chains. By providing product chain specific information documents could offer more insight on threats and vulnerabilities bespoke to a single food supply chain as well an inherit vulnerabilities associated with different raw materials, as well as testing methods available that could be used for fraud detection. This information would give the food industry specific information needed to build holistic prevention and mitigation plans.

In addition to the guidance documents, there are also a variety of tools available to the food industry to aid in food fraud mitigations, including tools to determine food fraud vulnerability, and identify what is susceptibility to food fraud within a company or supply chain (Spink et al., 2017). Identified vulnerabilities are then used as a basis for food fraud prevention and mitigation programs. Another tool often issued is horizon scanning, which refers to the act of proactively looking for and analysing threats and opportunities that may emerge in the medium to long term (Food Fraud Advisers, 2020; Ulberth, 2016). Manning and Soon (2019) and Ulberth (2020) have summarized vulnerability assessment tools in recent publications, several of these are summarized below:

- SSAFE Food Fraud Vulnerability Assessment (FFVA) tool- SSAFE is a non-profit organization that aims to set up a globally accepted internationally recognized food protection systems and standards (SSAFE, 2017). SSAFE, in collaboration with PwC, and Wageningen University, have developed the SSAFE FFVA, an online tool that is free of charge and can be used by food operators across the food supply chain of any size, geographical location, or type of food business. This tool helps companies identify food fraud vulnerability in their business. 

detection plans (PwC, 2020).

- $\quad$ EMAlert - This software tool was developed by The Grocery Manufacturers Association (GMA), and Battelle enables food manufacturers to analyse and understand EMA vulnerabilities (Manning \& Soon, 2019; EMAlert, 2019). This tool estimates an organization's vulnerability to EMA, then prioritize mitigation efforts associated with EMA threats. Manning and Soon (2019) highlight an advantage this system provides to the food industry as it can assess a large number (50) of commodities in one analysis.

The Rapid Alert System for Food and Feed (RASFF) portal - RASFF is a free resource database which is open to anyone, maintained by the European Commission (EC) under regulation $\mathrm{EC} / 178 / 2002$. Under this legislation, member states are legally required to report information concerning direct and indirect risks to human health from food or feed (European Food Safety Authority (EFSA), 2010). Reports on RASFF include the type and date of notification, the reason for notification, the hazard(s), the nature of the product involved,

- HorizonScan - HorizonScan is a privatized subscription-based system operated by the Food the country of notification, and the country of origin (EFSA, 2010; Djekic, Jankovic \& Rajkovic, 2017). Although this is a database used to record and food safety incidents, it has and Environment Research Agency (Fera) in the UK. It is a popular tool used by the food industry throughout the EU. HorizonScan monitors the safety and integrity issues of food commodities globally by collecting data from over 100 sources daily (FERA, 2020). 

HorizonScan risk assesses and analyses trends in reports to identify potential food safety issues before they escalate to more significant threats within the food supply chain (FERA, 2020).

- Decernis - The Decernis Food Fraud database (formerly The US Pharmacopeial (USP) Food Fraud Database) is available through subscription. This database focuses solely on food fraud and provides records of potential food fraud incidents from government, media, and academic sources. Decernis provides a list of potential adulterants, as well as information on testing techniques for each product in the database (Everstine, 2018).

- Food Industry Intelligence Network (Fiin) - Fiin was created in 2015 by industry leaders. Its development was the result of recommendations made in the Elliott Review (DEFRA, 2014). Fiin started with 21 founding member which has since grown to 46 members (as of 2019); these members include retailers, manufacturers, and foodservice companies (DEFRA, 2020; Campden BRI, 2019). Campden BRI is responsible for creating a database to collect anonymized industry data from Fiin members on food authenticity testing. This data is analyzed to produce quarterly reports for the Fiin members and is the only such scheme that exists globally. of Food was created by the Food Protection and Defense Institute (FPDI). For each product in the World Factbook of Food, information is provided on the production, trade, seasonality, processing steps, supply chain structure, food safety concerns, and past food 

database for food and is available on a subscription basis (DEFRA, 2020).

A combination of the tools listed above could be utilized to create a holistic prevention plan for food fraud. All businesses can use SSAFE in order to get a baseline of where they may be vulnerable. Then RASFF, HorizonScan, and Decernis can be used individually or in combination with each other to horizon scan for current and potential threats in supply chains. Fiin is a tool that should be utilized by larger companies that have the capability to do so. Unlike RASFF, HorizonScan, and Decernis, Fiin provides data concerning testing which is on-going in the food industry-giving greater insight into where the food chain is protected and where information is lacking and supply chains may be vulnerable. World Factbook can give information on product seasonality and trade, which can contribute to when a commodity is most likely to be adulterated, while Decernis gives information on testing, which is carried out to determine the adulterants. Together the World Factbook and Decernies could be used to create a food fraud detection program. Other research can be used in place of the aforementioned tools to determine vulnerabilities and created food fraud prevention plans. However, these tools can be uses to save time and give quick and accurate information, which could be particularly useful for companies with numerous types of food products and supply chains.

In addition to these tools, there are a wide variety of traceability technologies available to ensure the authenticity of a commodity/product. Traceability technologies aim to create more transparency in the supply chain, making it impossible for fraudulent products to enter (van Ruth et al.,2018; Yiannas, 2018). Technologies such as blockchain and other forms of digitized technologies can trace products back to processors and even back to the farm rapidly and create a chain of transactions concerning products which have to been to date un-hackable (Charlebois 2017; Yiannas, 2018). 
Software which passes data up and down supply chains and provides instant viewing, management, and reports on the quality, traceability, and compliance of their products and suppliers (Muddy Boots, 2020).

Food fraud is undefined by the EU, leading to the creation of numerous definitions from researchers and regulatory bodies, which has confused the understanding of food fraud and related terms. This makes it challenging to fully comprehend and form clear communication surrounding food fraud and how to prevent it. Through this review, commonalities between definitions of food fraud have been identified as intentionally deceptive acts for economic gain using food. Additionally, types of food fraud have been identified by multiple researchers in an ongoing effort to describe how food fraud might occur. Research in this area is built from previous publications and is still evolving. Some research name particular types of fraud, while others define it more in general terms. However, clarity on how food fraud can occur in specific supply chains would provide the food industry with the knowledge to help with prevention and mitigate fraud.

Food fraud prevention and mitigation has become a focus of researchers, legislators, and the food industry. Several documents are available to help guide the industry in food fraud prevention and mitigation methods. However, only one document found in this review is bespoke to a specific supply chain (Guidance on Authenticity of Herbs and Spices). Therefore there is a substantial gap in knowledge in this area. This paper argues that to help the food industry develop better food fraud prevention and mitigation methodologies guidance should be developed for individual supply chains. Supply chain specific guidance will help clarify any ambiguity in how fraud may be occurring and where specific prevention and mitigation efforts should focus. 
610 This EIT Food activity has received funding from the European Institute of Innovation and Technology

611 (EIT), a body of the European Union, under Horizon2020, the EU Framework Programme for Research 612 and Innovation.

613

614 EIT Food is Europe's leading agri-food innovation initiative, with the aim to create a sustainable and

615 future-proof food sector. The initiative is made up of a consortium of key industry players, start-ups, research centres and universities from across Europe. EIT Food aims to collaborate closely with consumers to develop new knowledge and technology-based products and services that will ultimately deliver a healthier and more sustainable lifestyle for all European citizens. a better understanding of food fraud prevention and mitigation strategies for the beef industry.

622

623 
631

\section{References}

Bosley, C. (2007). German kebab sales slump after rotten meat scandal. Reuters. Retrieved January 31, 2010 from http://www.reuters.com/article/idUSLA76533220070903

Bouzembrak, Y., Steen, B., Neslo, R., Linge, J., Mojtahed, V., \& Marvin, H. J. P. (2018). Development of food fraud media monitoring system based on text mining. Food Control, 93, 283-296. https://doi.org/10.1016/i.foodcont.2018.06.003

BRC, British Retail Consortium. (2018). Global Food Safety Standard (Issue 8). British Retail Consortium

Brooks, S., Elliott, C. T., Spence, M., Walsh, C., \& Dean, M. (2017). Four years post-horsegate: an update of measures and actions put in place following the horsemeat incident of 2013. npj Science of Food, 1(1), 1-7. https://doi.org/10.1038/s41538-017-0007-z

BSI, British Standards institution. (2020). PAS 96- Food and Drink Defence. BSIgroup. Retrieved January 23, 2020, from https://www.bsigroup.com/en-GB/PAS-96/

Campden BRI. (2019). Food industry intelligence network (fiin) final report quarter 3 2019. Campden BRI.

Cawthorn, D. M., Steinman, H. A., \& Hoffman, L. C. (2013). A high incidence of species substitution and mislabelling detected in meat products sold in South Africa. Food Control, 32(2), 440449. https://doi.org/10.1016/i.foodcont.2013.01.008

CEIN, Chartered Institute of Environmental Health (2016). Counter fraud good practice for food and drinks businesses. Chartered Institute of Environmental Health. Retrieved February 18, 2020, from, https://www.cieh.org/media/1240/counter-fraud-good-practice-for-food-and-drinkbusinesses.pdf 
CEN, European Committee for Standardization. (2018). CEN/CW 86 - Project Plan for the CEN Workshop - Authenticity in the feed and food chain - General principles and basic requirements - Workshop (approved during the kick-off meeting on 2017-05-11), Retrieved February 2, 2020 from ftp://ftp.cencenelec.eu/CEN/WhatWeDo/Fields/Food/WS/86/ProjectPlan.pdf

CEN, European Committee for Standardization. (2019). CWA 17369: Authentic and fraud in the feed and food chain- Concepts, terms and definitions. CEN-CENELEC Management Centre.

Charlebois, S. (2017). How blockchain technology could transform the food industry. Retrieved February 18, 2020, https://theconversation.com/how-blockchain-technology-couldtransform-the-food-industry-89348

Charlebois, S., Schwab, A., Henn, R., \& Huck, C. W. (2016). Food fraud: An exploratory study for measuring consumer perception towards mislabeled food products and influence on selfauthentication intentions. Trends in Food Science \& Technology, 50, 211-218. https://doi.org/10.1016/i.tifs.2016.02.003

CRS, Congressional Research Service. (2014). Food fraud and "Economically Motivated Adulteration" of Food and Food Ingredients. CRS. Retrieved February 18, 2020, from, https://fas.org/sgp/crs/misc/R43358.pdf

Cruse, C. (2019). Food Fraud and the Food, Drug, and Cosmetic Act: Bridging a Disconnect. Food \& Drug LJ, 74, 322.

DEFRA DERFA, United Kingdom Department for Environment, Food \& Rural Affairs. (2020). Food fraud Mitigation. Food Authenticity Network. Retrieved February 18, 2020, from http://www.foodauthenticity.uk/food-fraud-mitigation-guides\#g1

DEFRA, United Kingdom Department for Environment, Food \& Rural Affairs (2014). Elliott review into the integrity and assurance of food supply networks. HM Government. Retrieved February 2, 

2020 from https://www.gov.uk/government/uploads/system/uploads/attachment data/file/350726/el liot-review-final-report-july2014.pdf

Djekic, I., Jankovic, D., \& Rajkovic, A. (2017). Analysis of foreign bodies present in European food using data from Rapid Alert System for Food and Feed (RASFF). Food control, 79, 143-149. https://doi.org/10.1016/i.foodcont.2017.03.047

EC, European Commission (2017). Questions \& Answers on Commission Regulation (EC) No 2017/625 (Official Controls Regulation). Retrieved February 18, 2020, from https://ec.europa.eu/food/sites/food/files/safety/docs/oc qa ocregulation 20170407 en.p $\underline{\mathrm{df}}$

EC, European Commission (2020). The EU Food Fraud Network. Retrieved January 30, 2020, from https://ec.europa.eu/food/safety/food-fraud/food\%20fraudn en

EC, European Commission. (2018). The EU food fraud network and the system for administrative assistance -food fraud. Retrieved February 18, 2020, from https://ec.europa.eu/food/sites/food/files/safety/docs/foodfraud network activity report 2018.pdf

EC, European Commission. (2019). Legislation on official controls. Retrieved February 18, 2020 from https://ec.europa.eu/food/safety/official controls/legislation en

EFSA, European Food Safety Authority. (2010). Establishment and maintenance of routine analysis of data from the Rapid Alert System on Food and Feed. EFSA Journal, 8(1), 1449.10.2903/j.efsa.2010.1449

EIT Food and Queens University Belfast. (2020). Mapping the Agri-Food Chain. Panic-buying during a crisis: how do food supply chains cope?. Retrieved April 23, 2020, from https://www.futurelearn.com/courses/resilience-food-supply-chain/1/steps/754194 
Ellis, D. I., Brewster, V. L., Dunn, W. B., Allwood, J. W., Golovanov, A. P., \& Goodacre, R. (2012). Fingerprinting food: current technologies for the detection of food adulteration and contamination. Chemical Society Reviews, 41(17), 5706-5727.

\section{https://doi.org/10.1039/C2CS35138B}

Ellis, D. I., Muhamadali, H., Haughey, S. A., Elliott, C. T., \& Goodacre, R. (2015). Point-and-shoot: rapid quantitative detection methods for on-site food fraud analysis-moving out of the laboratory and into the food supply chain. Analytical Methods, 7(22), 9401-9414. $\underline{10.1039 / C 5 A Y 02048 D}$

EU FIP, European Union Food Integrity Project (2017). FoodIntegrity. Retrieved January 31, 2010 from https://secure.fera.defra.gov.uk/foodintegrity/index.cfm

Everstine, K., Spink, J., \& Kennedy, S. (2013). Economically motivated adulteration (EMA) of food: common characteristics of EMA incidents. Journal of food protection, 76(4), 723-735. https://doi.org/10.4315/0362-028X.JFP-12-399

FDA, Food and Drug Administration. (2009). Economically Motivated Adulteration; Public Meeting; Request for Comment [Docket No. FDA-2009-N-0166]. Federal Register, 74, 15497. Retrieved February 2, 2020 from http://edocket.access.gpo.gov/2009/pdf/E9--7843.pdf

FDF, Food and Drink Federation. (2014). Food authenticity five steps to help protect your business from food fraud. Retrieved February 18, 2020, https://www.fdf.org.uk/corporate pubs/Food-Authenticity-guide-2014.pdf

FDF, Food and Drink Federation. (2016). Guidance on Authenticity of Herbs and Spice. Retrieved February 2, 2020 from https://www.fdf.org.uk/corporate pubs/guidanceherbsandspices.pdf 
FERA, Food and Environment Research Agency. (2020). A technology-led solution for managing complex supply chains. Retrieved June 12020 , from https://www.fera.co.uk/foodsafety/support-tools/horizon-scan

Food Fraud Advisors. (2020). Horizon scanning for food fraud. Food fraud Advisors. Retrieved February 2, 2020, from https://www.foodfraudadvisors.com/horizon-scanning-for-foodfraud/

FPDI, Food Protection and Defense Institute. (2017). https://facts.foodprotection.io/about

FSSC 22000, Foundation Food Safety System Certification 22000. (2019). FSSC 22000 scheme version 5. Retrieved February 18, 2020, from https://www.fssc22000.com/wpcontent/uploads/19.0528-FSSC-22000-Scheme-Version-5.pdf

FSSC 22000. (2018). Guidance on Food Fraud Mitigation. FSSC 22000. Retrieved February 18, 2020, from https://www.fssc22000.com/wp-content/uploads/fssc-22000-guidance-on-food-fraudfinal-100418.pdf

Galvin-King, P., Haughey, S. A., \& Elliott, C. T. (2018). Herb and spice fraud; the drivers, challenges and detection. Food Control, 88, 85-97. https://doi.org/10.1016/j.foodcont.2017.12.031

GFSI, Global Food Safety Initiative (2017). Process manual for the GFSI benchmarking process v7.2, GFSI. Retrieved February 2, 2020 from https://mygfsi.com/wpcontent/uploads/2019/09/Benchmarking Requirements v7 2 Manual.pdf

GFSI, Global Food Safety Initiative. (2014). GFSI position on mitigating the public health risk of food fraud. Retrieved April 27, 2020, from https://mygfsi.com/wpcontent/uploads/2019/09/Food-Fraud-GFSI-Position-Paper.pdf

GFSI, Global Food Safety Initiative. (2018). Tackling food fraud through food safety management systems. GFSI. Retrieved February 20, 2020, from https://mygfsi.com/wpcontent/uploads/2019/09/Food-Fraud-GFSI-Technical-Document.pdf 
Hayneys, B. \& Spagnuol, S. (2017). Brazil police raid BRF and JBS meat plants in bribery probe. Retrieved 13 March, 2019, from https://www.reuters.com/article/us-brazil-corruptionfood/brazil-police-raid-brf-and-jbs-meat-plants-in-bribery-probe-idUSKBN1601LH.

Kowalska, A., Soon, J. M., \& Manning, L. (2018). A study on adulteration in cereals and bakery products from Poland including a review of definitions. Food Control, 92, 348-356. https://doi.org/10.1016/i.foodcont.2018.05.007

Kulling, S., Bunzel, D., Frommherz, L., Molkentin, J., Lehmann, I., Engert, S., \& Steinberg, P. (2019). The Setup of the National Reference Centre for Authentic Food (NRZ-Authent) in Germany. European Journal of Lipid Science and Technology, 121(12), 1900023. https://doi.org/10.1002/ejlt.201900023

Lotta, F., \& Bogue, J. (2015). Defining food fraud in the modern supply chain. Eur. Food \& Feed L. Rev., 10, 114.

Manning, L. (2016). Food fraud: Policy and food chain. Current Opinion in Food Science, 10, 16-21. https://doi.org/10.1016/i.cofs.2016.07.001

Manning, L., \& Soon, J. M. (2014). Developing systems to control food adulteration. Food Policy, 49, 23-32. https://doi.org/10.1016/j.foodpol.2014.06.005

Manning, L., \& Soon, J. M. (2016). Food safety, food fraud, and food defense: a fast evolving literature. Journal of food science, 81(4), R823-R834. https://doi.org/10.1111/1750$\underline{3841.13256}$

Manning, L. (2019). Food defence: Refining the taxonomy of food defence threats. Trends in Food Science \& Technology, 85, 107-115.

Manning, L., \& Soon, J. M. (2019). Food Fraud Vulnerability assessment: reliable data sources and effective assessment approaches. Trends in Food Science \& Technology. https://doi.org/10.1016/i.tifs.2019.07.007 
McGrath, T. F., Haughey, S. A., Patterson, J., Fauhl-Hassek, C., Donarski, J., Alewijn, M., ... \& Elliott, C. T. (2018). What are the scientific challenges in moving from targeted to non-targeted methods for food fraud testing and how can they be addressed?-Spectroscopy case study. Trends in food science \& technology, 76, 38-55. https://doi.org/10.1016/j.tifs.2018.04.001

Merriam-Webster. https://www.merriam-webster.com/

Mousavi, S. M., Khaniki, G. J., Eskandari, S., Rabiei, M., Samiee, S. M., \& Mehdizadeh, M. (2015). Applicability of species-specific polymerase chain reaction for fraud identification in raw ground meat commercially sold in Iran. Journal of Food Composition and Analysis, 40, 47-51. https://doi.org/10.1016/i.jfca.2014.12.009

Moyer, D. C., DeVries, J. W., \& Spink, J. (2017). The economics of a food fraud incident-Case studies and examples including Melamine in Wheat Gluten. Food Control, 71, 358-364. https://doi.org/10.1016/i.foodcont.2016.07.015

Muddy Boots. (2020). Home. Retrieved April 13, 2020, from https://en.muddyboots.com/

Nestle. (2016).Food fraud Prevention. Nestec Ltd. Retrieved February 18, 2020, from https://www.nestle.com/sites/default/files/assetlibrary/documents/library/documents/suppliers/food-fraud-prevention.pdf

NFCU, National Food Crime Unit (2016). Working Together to Tackle the Threat from Food Crime. NFCU. Retrieved February 18, 2020, from https://www.food.gov.uk/sites/default/files/media/document/tacklingfoodcrime-nfcu.pdf

NFCU, UK National Food Crime Unit. (2019a). Food Crime. Retrieved January 31, 2010 from https://www.food.gov.uk/safety-hygiene/food-crime from https://www.food.gov.uk/about-us/national-food-crime-unit. 
800

801

802

803

804

805

806

807

808

809

810

811

812

813

814

Primrose, S., Woolfe, M., \& Rollinson, S. (2010). Food forensics: methods for determining the authenticity of foodstuffs. Trends in Food Science \& Technology, 21(12), 582-590. https://doi.org/10.1016/j.tifs.2010.09.006

PwC, PricewaterhouseCoopers. (2016). Food fraud Vulnerability Assessment and Mitigation. PwC Retrieved February 18, 2020, from https://www.pwc.com/gx/en/services/food-supplyintegrity-services/assets/pwc-food-fraud-vulnerability-assessment-and-mitigation$\underline{\text { november.pdf }}$

PwC, PricewaterhouseCoopers. (2020). Food fraud vulnerability assessment. https://www.pwc.com/gx/en/services/food-supply-integrity-services/food-fraud$\underline{\text { vulnerability-assessment.html }}$

Rahmati, S., Julkapli, N. M., Yehye, W. A., \& Basirun, W. J. (2016). Identification of meat origin in food products-A review. Food Control, 68, 379-390. https://doi.org/10.1016/i.foodcont.2016.04.013

Robson, K., Dean, M., Brooks, S., Haughey, S., \& Elliott, C. (2020). A 20-year analysis of reported food fraud in the global beef supply chain. Food Control, 107310. https://doi.org/10.1016/j.foodcont.2020.107310

RQA Group. (2016). Food Supply Chain Vulnerability: A Ti whitepaper in partnership with RQA Group. Retrieved February 18, 2020, http://www.rqa-group.com/wpcontent/uploads/2016/12/RQA Ti-Food-Supply-Chain-Vulnerability-Whitepaper.pdf

Sentandreu, M. Á., \& Sentandreu, E. (2014). Authenticity of meat products: Tools against fraud. Food Research International, 60, 19-29. https://doi.org/10.1016/i.foodres.2014.03.030

Shears, P. (2010). Food fraud-a current issue but an old problem. British Food Journal. 
Soon, J. M., Krzyzaniak, S. C., Shuttlewood, Z., Smith, M., \& Jack, L. (2019). Food fraud vulnerability assessment tools used in food industry. Food control, 101, 225-232. https://doi.org/10.1016/j.foodcont.2019.03.002

Spink, J. \& Harte, B. (2008). Academic food stuff, a strategy to combat economic food fraud. Packaging World Magazine, 29. Retrieved February 2, 2020, from https://www.packworld.com/article-25733

Spink, J. (2019). The current state of food fraud prevention: overview and requirements to address "How to Start?" and "How Much is Enough?". Current Opinion in Food Science. https://doi.org/10.1016/j.cofs.2019.06.001

Spink, J., \& Moyer, D. C. (2011). Defining the public health threat of food fraud. Journal of food science, 76(9), R157-R163. https://doi.org/10.1111/j.1750-3841.2011.02417.x

Spink, J., Bedard, B., Keogh, J., Moyer, D. C., Scimeca, J., \& Vasan, A. (2019a). International Survey of Food fraud and Related Terminology: Preliminary Results and Discussion. Journal of food science, 84(10), 2705-2718. https://doi.org/10.1111/1750-3841.14705

Spink, J., Chen, W., Zhang, G., \& Speier-Pero, C. (2019b). Introducing the food fraud prevention cycle (FOOD FRAUDPC): A dynamic information management and strategic roadmap. Food Control, 105, 233-241.

Spink, J., Hegarty, P. V., Fortin, N. D., Elliott, C. T., \& Moyer, D. C. (2019c). The application of public policy theory to the emerging food fraud risk: Next steps. Trends in food science \& technology, 85, 116-128. https://doi.org/10.1016/i.tifs.2019.01.002

Spink, J., Moyer, D. C., \& Speier-Pero, C. (2016). Introducing the food fraud initial screening model (FFIS). Food control, 69, 306-314. https://doi.org/10.1016/i.foodcont.2016.03.016 
Spink, J., Moyer, D. C., \& Whelan, P. (2016). The role of the public private partnership food fraud prevention-includes implementing the strategy. Current Opinion in Food Science, 10, 68-75. https://doi.org/10.1016/j.cofs.2016.10.002

Spink, J., Moyer, D. C., Park, H., Wu, Y., Fersht, V., Shao, B., ... \& Edelev, D. (2015). Introducing Food Fraud including translation and interpretation to Russian, Korean, and Chinese languages. Food chemistry, 189, 102-107. https://doi.org/10.1016/j.foodchem.2014.09.106

Spink, J., Ortega, D. L., Chen, C., \& Wu, F. (2017). Food fraud prevention shifts the food risk focus to vulnerability. Trends in Food Science \& Technology, 62, 215-220. https://doi.org/10.1016/j.tifs.2017.02.012

SSAFE. (2017). About SSAFE. Retrieved February 2, 2020, from http://www.ssafe-food.org/aboutssafe/

Sumar, S., \& Ismail, H. (1995). Adulteration of foods-past and present. Nutrition \& Food Science. System. Retrieved 14 March, 2019, from https://www.fera.co.uk/media Lwysiwyg/HorizonScan Leaflet.pdf

Tähkäpää, S., Maijala, R., Korkeala, H., \& Nevas, M. (2015). Patterns of food frauds and adulterations reported in the EU rapid alert system for food and feed and in Finland. Food Control, 47, 175-184. https://doi.org/10.1016/j.foodcont.2014.07.007

Trivedi, D. K., Hollywood, K. A., Rattray, N. J., Ward, H., Trivedi, D. K., Greenwood, J., ... \& Goodacre, R. (2016). Meat, the metabolites: an integrated metabolite profiling and lipidomics approach for the detection of the adulteration of beef with pork. Analyst, 141(7), 2155-2164.

\subsection{9/C6AN00108D}

Ulberth, F. (2016). Early warning systems for food safety and integrity need to be anticipative to be useful for preventing food crisis situations. https://doi.org/10.1007/s00003-016-1041-5 
Ulberth, F. (2020). Tools to combat food fraud-a gap analysis. Food Chemistry, 127044. https://doi.org/10.1016/i.foodchem.2020.127044

USP, U.S Pharmacopeial Convention. (2016). Food fraud mitigation guidance. The United States Pharmacopeial Convention. Retrieved February 18, 2020, from https://www.usp.org/sites/default/files/usp/document/our-work/Foods/food-fraud$\underline{\text { mitigation-guidance.pdf }}$

van Ruth, S. M., Huisman, W., \& Luning, P. A. (2017). Food fraud vulnerability and its key factors. Trends in Food Science \& Technology, 67, 70-75. https://doi.org/10.1016/j.tifs.2017.06.017

van Ruth, S. M., Luning, P. A., Silvis, I. C. J., Yang, Y., \& Huisman, W. (2018). Differences in fraud vulnerability in various food supply chains and their tiers. Food Control, 84, 375-381. https://doi.org/10.1016/j.foodcont.2017.08.020

Wisniewski, A., \& Buschulte, A. (2019). How to tackle food fraud in official food control authorities in Germany. Journal of Consumer Protection and Food Safety, 14(4), 319-328. https://doi.org/10.1007/s00003-019-01228-2

Yiannas, F. (2018). A new era of food transparency powered by blockchain. Innovations: Technology, Governance, Globalization, 12(1-2), 46-56. https://doi.org/10.1162/inov a 00266

Zhang, W., \& Xue, J. (2016). Economically motivated food fraud and adulteration in China: An analysis based on 1553 media reports. Food control, 67, 192-198. https://doi.org/10.1016/i.foodcont.2016.03.004 